\title{
Corrigendum to "High-resolution evidence from southern China of an early Holocene optimum and a mid-Holocene dry event during the past 18,000 years" [Quaternary Research 62 (2004) 39-48]
}

\author{
Weijian Zhou ${ }^{\text {a,d,*}}$, Xuefeng Yu ${ }^{\text {a }}$, A.J. Timothy Jull ${ }^{\text {b }}$, G. Burr ${ }^{\text {b }}$, J.Y. Xiao ${ }^{\text {c }}$, Xuefeng Lu ${ }^{\text {a }}$, Feng Xian ${ }^{\text {a }}$ \\ ${ }^{a}$ State Key Laboratory of Loess and Quaternary Geology, Institute of Earth Environment, Chinese Academy of Sciences, Xi'an 710075, China \\ ${ }^{\mathrm{b}}$ NSF-Arizona AMS Laboratory, P.O. Box 210081, University of Arizona, Tucson, AZ 85271, USA \\ ${ }^{\mathrm{c}}$ Department of Geography, Nanjing Normal University, Nanjing, 210097, China \\ ${ }^{\mathrm{d}}$ Xi'an Jiaotong University, Xi'an, 710052, China
}

Available online 2 June 2008

On page 40, line 21, the geographic coordinates of the Dahu Swamp are incorrect. Recently we again did field work at the Dahu Swamp location and remeasured the geographic coordinates using GPS. The correct geographic coordinates are $24^{\circ} 45^{\prime} \mathrm{N}, 115^{\circ} 02^{\prime} \mathrm{E}$.

On page 41, in Figure 1, the lowest line indicating the standing monsoon front around Dahu Swamp should be $3000 \mathrm{yr}$ BP instead of $6000 \mathrm{yr}$ BP. The corrected Figure 1 and legend are shown here.

\section{Acknowledgments}

We thank Prof. Zhong Wei and his group from South China Normal University for informing us about the geographic coordinate mistake. This work was supported by NSFC (40531003).

\section{References}

An, Z.S., Porter, S.C., Kutzbach, J.E., Wu, X.H., Wang, S.M., Liu, X.D., Li, X.Q., Zhou, W.J., 2000. Asynchronous Holocene optimum of the East Asian monsoon. Quaternary Science Review 19, 743-762.

Sun, X.J., Li, X., 1999. A pollen record of the last $37 \mathrm{ka}$ in deep sea core 17940 from the northern slope of the South China Sea. Marine Geology 156, 227-244.

Wang, Y.J., Cheng, H., Edwards, R.L., An, Z.S., Wu, J.Y., Shen, C.-C., Dorale, J.A., 2001. A high-resolution absolute-dated late Pleistocene monsoon record from Hulu Cave, China. Science 294, 2345-2348.

Zhou, Weijian, Donahue, D., Porter, S.C., Jull, T.A., Li, Xiaoqiang, Stuiver, M., An, Zhisheng, Eiji, Matsumoto, Dong, Guanrong, 1996. Variability of monsoon climate in east Asia at the end of the last glaciation. Quaternary Research 46, 219-229.

DOI of original article: 10.1016/j.yqres.2004.05.004.

* Corresponding author. State Key Laboratory of Loess and Quaternary Geology, Institute of Earth Environment, Chinese Academy of Sciences, Xi'an 710075, China. Fax: +86298320456.

E-mail address: Weijian@loess.1lqg.ac.cn (W. Zhou). 


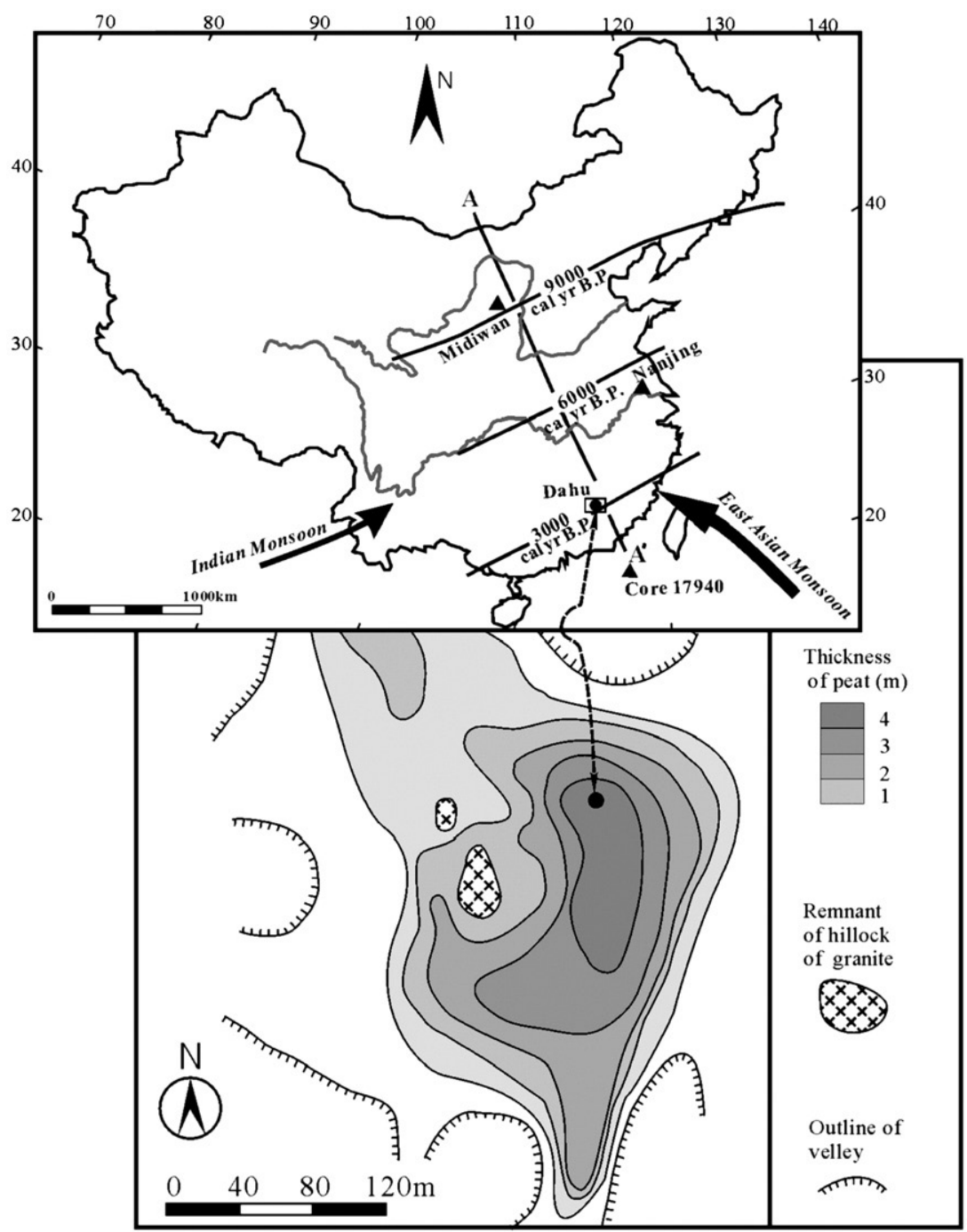

Figure 1. Map of the spatial variation of the East Asian monsoon front with time. The upper map shows that the time-transgressive Holocene Optimum (represented by the line standing for the monsoon front) would have been experienced $9000 \mathrm{cal}$ yr ago in northeastern China and in north-central China, $6000 \mathrm{cal}$ yr ago in the middle and lower reaches of the Yangtze River, and about $3000 \mathrm{cal}$ yr ago in southern China (An et al., 2000). The Dahu peat site (filled circle) is within the 3000 -yr front zone. The positions of the Hulu Cave speleothem site in Nanjing (filled triangle, Wang et al., 2001), Midiwan peat site from desert/loess boundary (filled triangle, Zhou et al., 1996), and the South China Sea deep sea core 17940 (filled triangle, Sun and Li, 1999) are also shown in the map. The arrowed line indicates the summer monsoon direction. The lower map is a detailed topographic diagram of the Dahu peat bog (altitude $\sim 250 \mathrm{~m}$ ) for this study. This location is in a wide mountain valley near the Guangdong and Jianxi provincial border. The valley is several kilometers in length and several hundred meters in width. The peat bog is thickest in the center and thins out toward the end. The black filled circle is the actual core sampling site. 